Open Access

\title{
Role of foreign direct investment on technology transfer and economic growth in Kenya: a case of the energy sector
}

Hezron M. Osano ${ }^{1 *}$ and Pauline W. Koine ${ }^{2}$

\author{
* Correspondence: \\ hezron.osano@gmail.com \\ ${ }^{1}$ Strategic Initiatives Consulting, P.O. \\ Box 5258600200 Nairobi, Kenya \\ Full list of author information is \\ available at the end of the article
}

\begin{abstract}
Foreign firms in Kenya have played a major role in enhancing economic growth in the agriculture sector, especially in floriculture and horticulture. Over a long period of time, foreign direct investment (FDI) has been found to create many externalities in the Kenyan economy in the form of benefits available through transfers of general knowledge, specific technologies in production and distribution, industrial upgrading, work experience for the labor force and the establishment of finance-related and trading networks, and the upgrading of telecommunications services. The purpose of this study was to address the role of foreign direct investment on technology transfer and economic growth in Kenya, with a focus on the energy sector in Nairobi focusing on the period between 2001 and 2014. This study adopted a descriptive and inferential survey design. The target population for this study was 60 senior managers composing of directors and managers from Kenya Power and Kengen. Questionnaires were used to collect primary data. The study established that there is a relationship between foreign direct investment variables of infrastructure, technology diffusion, trade facilitation, knowledge management, and technology transfer and economic growth. The study found that investment in the energy sector has led to new technology in the country as it has transferred technology to local investors through sharing of knowledge in new innovation in production, research, and development and also has led to increased competition in trading which has resulted in efficiency and effectiveness of the industry. A major implication of this study is that policy makers must devise policies that would create an enabling environment for attracting FDIs in order to facilitate technology transfer and hence economic growth.
\end{abstract}

Keywords: Foreign direct investment, Infrastructure, Technology transfer, Knowledge management and facilitation of trade and access to export market, Technology diffusion

\section{Introduction}

Several ways that transmission of ideas and technologies happen have been cited, which include international trade: imports of high-technology products (Coe and Helpman 1995; Coe et al. 1997; Kwark and Shyn 2006); foreign technology payment; direct adoption of foreign technology (Soete and Patel 1985); and acquisition of human capital (Park 2004; Le 2008; Le and Bodman 2011). In addition, foreign direct investment (FDI) is considered as one of the major conduits of technology diffusion

(c) The Author(s). 2016 Open Access This article is distributed under the terms of the Creative Commons Attribution 4.0 International License (http://creativecommons.org/licenses/by/4.0/), which permits unrestricted use, distribution, and reproduction in any medium, provided you give appropriate credit to the original author(s) and the source, provide a link to the Creative Commons license, and indicate if changes were made. 
across borders since the inflow of FDI contains knowledge about new technologies and materials, production methods, or organizational management skills (Bodman and Le 2013).

Bodman and Le (2013) studied the impact of technology embodied in FDI on the total factor productivity (TFP) of FDI-receiving countries, shedding new light on where the sources of research and development (R\&D) spillovers lie and directly addressing the important question of whether more FDI leads to a better trained labor force. Their findings are that countries that have embraced a relatively more open international investment regime have usually grown significantly faster than others who have not. It is suggested that the fact that FDI transmits technological knowledge, as well as contributing to the physical capital stock, openness to direct physical investment, as well as to trade and financial flows, provides an important driver of economic growth. It was also found that apart from human capital being necessary for the direct general enhancement of the technological level itself, it is also essential for the ability to learn from foreign technological sources.

The growth of international production is driven by economic and technological forces. It is also driven by the ongoing liberalization of FDI and trade policies. Hansen and Rand (2006) argue that the evidence that FDI generates positive spillovers for host countries is weak. Previously, scholars have either looked at the determinants of FDI Wanjala (2001), impact of local private investment (King'ang'i 2003), or researched on the greater regional implications without looking at the specific impact of foreign direct investment in areas such as development of infrastructure and technology transfer. Thus, this study sought to fill the existing knowledge gap to establish the effects of FDI on technology transfer and economic growth in Kenya focusing on the energy sector between 2004 and 2014. The study focused on the FDI elements (variables) relating to infrastructure, technology diffusion, knowledge management, and facilitation of trade and access to export markets.

\section{Background}

Zhang (2001) refers to FDI as long-term participation by a country in another country and that it usually involves participation in management, joint-venture, transfer of technology, and expertise. There are two types of FDI as indicated by Damooei and Tavakoli (2006), that is, inward foreign direct investment and outward foreign direct investment, resulting in a net FDI inflow (positive or negative). For an investment to be regarded as an FDI, the parent firm needs to have at least $10 \%$ of the ordinary shares of its foreign affiliates but investing firm may also qualify for an FDI if it owns voting power in a business enterprise operating in a foreign country (Sharma and Gani 2004).

The past few years have seen a tremendous growth of FDI that have exceeded both world output and world trade. In response to the adoption of the global policy, China's FDI abroad has increased rapidly during this decade. The growth of international production is driven by economic and technological forces. It is also driven by the ongoing liberalization of FDI and trade policies. In this context, globalization offers an unprecedented opportunity for developing countries to achieve faster 
economic growth through trade and investment. In the period of 1970s, international trade grew more rapidly than FDI, and thus, international trade was more popular than other important international economic activities (Rutihinda 2007). This situation changed dramatically in the middle of the 1980s, when world FDI started to increase sharply. In this period, the world FDI has increased its importance by transferring technologies and establishing marketing and procuring networks for efficient production and sales internationally (Swenson 2004). Through FDI, foreign investors benefit from utilizing their assets and resources efficiently, while FDI recipients benefit from acquiring technologies and from getting involved in international production and trade networks.

The determining factor for a particular firm to establish production facilities abroad is the prospect of earning higher profit which induces firms to invest abroad, primarily because of lower labor costs. Traditional theories on trade and investment assumed that factors of production, such as labor and capital, were not internationally traded (Rutihinda 2007).

Attracting FDI has been key drivers for Kenya and other developing countries, in its outward-oriented development strategy improving economic status (Kayonga 2008). FDI has come to swamp all other financial flows (World Bank 2004). Although FDI has increased in the recent past in Kenya, it remains difficult to quantify the exact magnitude of FDI basically because of the non-reporting problem. It is even more difficult to have correct estimate of sectorial FDI. The Board of Investment (BOI) keeps product category-wise records of registered investment (World Bank 2004). One approach to do this is to analyze the effect of FDI in Africa on a sectoral basis, and this study focuses on Kenya with a specific reference to the energy sector. The energy sector was declared by the UN Habitat as the fastest growing sector in Kenya, and this could partly be a result of the foreign investors who have investment interests in the sector and are involved in other activities in the country that are directly or indirectly spurring economic growth and development (Melitz and Gianmarco 2008).

According to World Bank (2008) and Economic Survey, net FDI flows to developing countries rose from US\$ 367 billion in 2006 to US\$ 471 billion in 2007. This accounted for more than $25 \%$ of global FDI inflows. Of the net FDI flows to developing countries in 2007, Europe and Central Asia accounted for 34\%, while Latin America and the Caribbean and East Asia and Pacific countries accounted for 23 and 25\%, respectively (UNCTAD 2008).

Damooei and Tavakoli (2006) argue that FDI is critical as it provides a major source of capital which brings with it up-to-date technology contributing to economic growth. It would be difficult to generate this capital through domestic savings, and even if it were not, it would still be difficult to import the necessary technology from abroad, since the transfer of technology to firms with no previous experience of using it is difficult, risky, and expensive (Sharma and Gan, 2004).

Todaro (2000) argues that FDI in services affects the host country's competitiveness by raising the productivity of capital and enabling the host country to attract new capital on favorable terms. Swenson (2004) contend that FDI improves its competitiveness through technology transfer and the effects of myriad externalities and foreign as well as domestic investment can alter a country's economic volume and pattern of trade in many income-enhancing directions (Ajayi 2007). 
African countries, with their huge development gaps, need foreign investments to boost their economies in order to lift their populations out of poverty. Over the last decade, FDI to Africa have increased on average in terms of both net inflows FDI per capita and ratio of FDI over total gross domestic product (GDP), while at the same time, real per capita GDP and the United Nations Development Program (UNDP)computed Human Development Index (HDI) were improving (Sharma and Gani 2004).

Foreign firms in Kenya played a major role in enhancing economic growth especially in the agriculture sector, floriculture and horticulture. Gachino and Rasiah (2003) noted that FDI has concentrated on the consumer goods sector, such as food and beverage industries, as well as on other sectors in the economy including services and telecommunication.

\section{Concept of economic growth}

According to Klein and Rosengren (1994), economic growth is the increase of per capita GDP or other measures of aggregate income, typically reported as the annual rate of change in real GDP. Economic growth is mainly driven by improvements in productivity, which involves producing more goods and services with the same inputs of labor, capital, energy, and materials. Economists draw a distinction between shortterm economic stabilization and long-term economic growth. The topic of economic growth is primarily concerned with the long run. The short-run variation of economic growth is termed the business cycle. The overall state of the economy fluctuates in all countries (Phillips and Obwana 2000).

An economy can be characterized by innumerable statistics on its demographic, economic, technological, and institutional features (Sharma and Gani 2004). The stock of knowledge includes not only the scientific knowledge, its distribution in the operations, and its application to solving problems of economic changes but also the beliefs that influence the choices made to mitigate the effects of economic changes. That stock of knowledge determines the potential upper bound of the well-being of the service industry specifically on the banks (Melitz and Gianmarco 2008). Kenya catches the attention of foreign investors due to its hub status in financial services, trade, shipping, and logistics. As a consequence, foreign investment in Kenya predominantly goes to the service sector.

Policy makers and scholars have argued that FDI can have important positive effects on a host country's development effort (Damooei and Tavakoli 2006). Over a long period of time, FDI has been found to create many externalities in the Kenyan economy in the form of benefits available to the whole economy through transfers of general knowledge, specific technologies in production and distribution, industrial upgrading, work experience for the labor force and the establishment of finance-related and trading networks, and the upgrading of telecommunications services.

However, the special merits of FDI and particularly the kinds of incentives offered to foreign firms in practice have begun to be questioned. Fueling this debate is the empirical evidence for foreign direct investment generating positive spillovers for host countries which is ambiguous at both the micro and macro levels. Hanson et al. (2001) argue that the evidence that FDI generates positive spillovers for host countries is weak. In a review of micro data on spillovers from foreign-owned to domestically owned 
firms, conclude that the effects are mostly negative. Previously, scholars have either looked at the determinants of FDI (Wanjala 2001) and the impact of local private investment (King'ang'i 2003) or researched on the greater regional implications without looking at the specific impact of foreign direct investment in the development of infrastructure and transfers of knowledge.

Promoting FDI has always been a primary concern for economic growth, especially in developing countries. The Chinese government has encouraged FDI in order to prop up backward industries (Sharma and Gani 2004). FDI is expected to force domestic firms to improve their technical efficiency, and domestic firms can benefit from technology spillovers from foreign entrants.

\section{Literature review}

This section reviews the pertinent literature about foreign direct investments. Foreign direct investments and how it improves productivity in the destination country are reviewed. In addition, the effect of foreign direct investments on the growth of investments is reviewed.

\section{Theoretical review}

There are various theories addressing the influence of FDI on the growth of the economy such as Marginal Efficiency of Investment (MEI) and Accelerator Theories, Keynesian Theory of Economics, and neoclassical theory.

This study was guided by Keynesian Theory of Economics. If there are underutilized resources in developed countries, which could not be activated due to balance of payments constraints, international aid will be mutually profitable by channeling such resources to developing countries (Durham 2004). The economic motive was also in the self-interest of the developed nations to invest in developing nations to raise their own welfare. Therefore, the role of foreign direct investment is to improve economic growth of a country

\section{Empirical review}

FDI refers to long-term participation by a country in another country, and this involves participation in management, Zhang (2001), joint-venture, transfer of technology, and expertise. There are two types of FDI as indicated by Damooei and Tavakoli (2006), that is, inward foreign direct investment and outward foreign direct investment, resulting in a net FDI inflow (positive or negative). For an investment to be regarded as an FDI, the parent firm needs to have at least $10 \%$ of the ordinary shares of its foreign affiliates, but investing firm may also qualify for an FDI if it owns voting power in a business enterprise operating in a foreign country (Sharma and Gani 2004).

Technology transfer is achieved by a country though licensing agreements and outright purchase; purchasing foreign capital goods; DFI inflows; turnkey projects; and various forms of international technical assistance. During its development process, Japan relied heavily on licensing, turnkey projects, and the reverse engineering of imported goods while in the case of Korea, they relied on machinery imports and turnkey projects (Kakazu 1990). 
It is acknowledged that technology upgrading constitutes a critical element of the development process. In this regard, the Association of Southeast Asian Nations (ASEAN) member countries placed a strong emphasis on attracting DFI flows as a means of promoting technology transfer (Montes 1997).

It is argued that technology transfer through FDI has the effect of stimulating competing firms in the domestic market to carry out technological upgrading. Employees can also learn the technology while working for the firm, and some of them may start their own ventures using the acquired technology (Chia 1997).

In their respective positions towards DFI and technological upgrading, ASEAN economies have exhibited a diversity strongly conditioned by their economic situation and policy experience (Chia 1993).

The common thread in the ASEAN experience included; ASEAN economies consistently sought multinational production technology for purpose of modernizing their manufacturing sector with economies undertaking an import-substitution strategy seeking external investments in the "mainline" development industries such as textile production and automobile assembly, eventually switching to export-promotion stances, seeking multinational enterprises (MNEs) serving global markets; provision of investment incentives and assistance for upgrading of labor skills; and undertaking policies, including lower tariffs or duty-free importation and tax deductions for various categories of costs, to assist companies relocating their production in reducing variable production costs, especially in the sourcing of inputs (Montes 1997).

Empirical studies found that FDI is positively correlated with economic growth. Empirical studies relating economic growth to capital formation have concluded that gross domestic investment (GDI) exerts a major influence on economic growth. The positive effects of FDI come largely from technology transfer, knowledge and other intagible assets, resulting in productivity increase and improvements in efficiency in resource allocation (Graham 1995). Studies by Zhang (2001) found that there existed a positive relationship between FDI and economic growth. Their studies analyzes the causality between FDI and economic growth where Zhang uses data for 11 developing countries in East Asia and Latin America and, using cointegration and Granger causality tests, found that in five cases, economic growth is enhanced by FDI but that host country conditions such as trade regime and macroeconomic stability are important (Phillips and Obwana 2000).

It can also be argued that some firms pursue international expansion through foreign direct investment as a result of supply, demand, and political factors which favor such type of global expansion. It is also contended that given the complexity of the global economy and the diversity of opportunities that firms face in different countries, it is not surprising that numerous factors may influence a firm's decision to undertake FDI (Griffin and Pustay 2002).

A number of supply factors that affect decisions of firms to be involved in FDI can be identified, which include the need to lower production costs. Firms may utilize FDI to access natural resources that are critical to their operations. Often, international firms negotiate with host governments to obtain access to raw materials in return to FDI. Lastly, firms may find it more advantageous to acquire ownership interests in an existing firm than assemble an in-house group of research scientists to develop or reproduce an emerging technology. The foreign firm also gains from "buy local" attitudes of host country consumers. Firms may also engage in FDI to improve their customer 
service. It is further argued that FDI may be a firm's best means to exploit a competitive advantage that it already enjoys. An owner of a valuable trademark, brand name, or technology may choose to operate in foreign countries rather than export to them. Finally, a firm's FDI also may be motivated by FDI of its customers or clients (Griffin and Pustay 2002).

It can also be argued that political factors are important considerations and they range from the fact that firms often build foreign facilities to avoid trade barriers or take advantage of economic development incentives; most governments-local, state, and national-are concerned with promoting the economic welfare of their citizens (Griffin and Pustay 2002).

It is contended in conventional theory that FDI is an attempt by investors to exploit firm-specific assets in foreign markets. FDI allows multinational firms to extract from the host country economic rent that is unobtainable through other means of trade, such as export or licensing. It is further argued that due to the nature of rent extraction, FDI carries the connotation that the capital-rich countries exploit capital-poor countries despite the fact that FDI may also prove to be ultimately beneficial to the host country. In contrast, the network approach to FDI highlights the exploitation of network resources for internationalization. Even a small and seemingly weak firm may engage in FDI as long as it can successfully leverage external resources. Through FDI, an investor builds new relationships in a foreign country in order to secure those essential relationships. FDI facilitates linkages between the domestic and overseas networks, allowing an investor to internalize some technical and managerial assets within its organization while gaining access to a pool of external resources. These new resources propel the firm to make further investments (Chen 2003).

In relation to the country/market choice, there is evidence of companies directing their efforts to countries that are closest in terms of "psychic distance" (a concept which takes into account both physical and cultural distances). Other important actors include entry and development methods which concern the choice between exporting, licensing, and FDI. The most strongly FDI-oriented sectors include electronics, pharmaceuticals, oil and food, drink, and tobacco. In other cases of anti-dumping allegations, the firms involved may decide to establish manufacturing plants in those countries they export to such as in cases of Korean and Japanese firms (Young et al. 1989; Young 1998).

It is argued that enterprises in developing countries generally start the innovation and learning process by importing new technology and then investing in building their capabilities to master the tacit elements. How much they invest depends on the incentives thrown up by markets, mainly by the competition faced in foreign and domestic markets, as well as, on the ability to access complementary supporting activities. Enterprises draw on internal and external resources-both foreign and domestic-to build their capabilities The process starts with capabilities needed to master the technology for production purposes and may deepen over time into improving the technology and creating new technology. It is further argued that linking, leveraging, and learning capture what enterprises-and countries-have to do to enable their technological development. Thus, linking is connecting with outsiders to acquire needed technologies and skills; leveraging is going beyond arms-length transactions to squeeze as much as possible from the new relationships with those 
outsiders; and learning is making many efforts to master process and product technologies, consciously building the foundation for improving current technologies and creating new ones (UNIDO 2004).

It has been observed that repeated application of linkage and leverage processes may result in the firm learning to perform such operations more effectively (organizational learning). It is suggested that the entire regions or economies may learn the processes involved more effectively, as they master the intricacies of cluster development, for instance, or formation of more effective R\&D alliances (Mathews 2005).

Competing in global value chains can build foundations and learning. Particularly in manufacturing, the insertion of local activities in wider networks is an opportunity for developing countries to upgrade their capabilities. It is argued that collaboration with other firms and institutions in R\&D offers possibilities for knowledge transfer, resource exchange, and organizational learning. Joint $R \& D$ within well-organized networks enhances the innovation activities of cooperating partners, which increases the probability of realizing new products (Becker and Dietz 2004; Koschatzky et al. 2001; Plunket et al. 2001).

It is also argued that the creation, through $\mathrm{R} \& \mathrm{D}$, and diffusion of new technology is a major determinant of economic growth (Findlay 1978; Romer 1990; Grossman and Helpman 1991; Aghion and Howitt 1992, 1998). It also argued that in the globalization process, as countries become more open to international trade, FDI, and international technological diffusion, domestic production and productivity growth can also depend on R\&D activities of other countries (Bodman and Le 2013).

Researchers have postulated that there are effects of own R\&D capital formation and international technological spillovers on a country's production structure and productivity. In addition, it is argued that domestic R\&D expenditure is important for output and productivity growth and there exists a channel through which R\&D capital formation in one country affects the production pattern and productivity in another (Chen 2002; 2004; Coe and Helpman 1995; van Pottelsberghe and Lichtenberg 2001; Park 2004; Le 2008).

FDI is an effective conduit for technology transfer through technology spillovers to domestically owned firms in the host country. Managi and Bwalya (2010) analyzed the nature and occurrence of technology spillovers from foreign to local firms in the manufacturing sector in Kenya, Tanzania, and Zimbabwe. Support was found for horizontal (intra-industry) productivity spillovers and vertical (inter-industry) technology spillovers from foreign firms in upstream sectors to local firms in downstream sectors in the case of Kenya and Zimbabwe. However, support was only found for regional technology spillovers that industrial clustering speed up the rate of technology diffusion to local firms in the case of Tanzania.

Le and Pomfret (2011), in a study of Vietnam firms, found that domestic firms gain technology spillovers through vertical linkages with foreign firms, but the effect of the horizontal presence of foreign firms on the productivity of domestic firms was negative. They argued that it suggested that potential technology transfer between foreign firms and their local competitors is more than offset by the competition induced by the entry of foreign firms and the existence and strength of horizontal and vertical spillovers depended on industry and firm characteristics and on the types of FDI.

Abor et al. (2008) found that FDI has a positive effect on firms' decision to export as well as their export performance. This was attributed to the fact that FDI brings on 
board improved technologies and management skills that would translate into efficiency and productivity. In addition, firms with foreign capital injection may be in a better position to finance the sunk cost involved in entering the export market and also foreign-owned firms may have links with foreign markets and therefore would be motivated to export.

On the one hand, Modarress et al.'s (2014) findings indicate that there has been a significant transfer of technology to the UAE, which has had a positive impact on human capital formation. However, they did not find conclusive evidence of the relationships between technology transfer and income inequality or economic growth.

The dilemma faced by governments in developing countries is what they can do to facilitate technological learning in such a dynamically changing global technology environment. It is postulated that technology policies would be analyzed in three perspectives: market mechanism, technology flow, and time. Three components related to market mechanism are identified. The components encompass policies designed to strengthen the demand side, creating market needs for technology; policies designed to strengthen the supply side, increasing science and technology (S\&T) capabilities; and policies designed to provide effective linkages between the demand and supply sides, attempting to ensure that innovation activities are both technically and commercially successful. It is argued that unless there is a competitive market, there will be little investment in innovation activities, as innovation is usually uncertain and risky. Consequently, S\&T policies should be an integral part of the overall industrial policies which shape market structure and industrial development. The first sequence involves technology transfer from abroad through such formal mechanisms as FDI, the purchase of turnkey plants and machinery, foreign licenses (Flesh), and technical services (Hobday 1995; Kim and Dahlman 1992).

Dynamic perspective is added as the third dimension to reflect the impact of technology flow and market mechanism changes as industries in developing countries advance through different stages of development over time. Firms also need to have an effective strategy in creating the demand for new technology in the market, developing supply (R\&D) capability, and coupling the market demand with R\&D capability. It is also important for firms to have an effective strategy in the acquisition of foreign technology and the diffusion of imported technology within firms and in-house R\&D (Hobday 1995; Kim and Dahlman 1992).

It is argued that effective diffusion of imported technology within an industry and across industries is a second sequence in upgrading technological capability of an economy. The third sequence involves local efforts to assimilate, adapt, and improve imported technology and eventually to develop one's own technology. These efforts are crucial to augmenting technology transfer and expediting the acquisition of technological capability. Technology may be transferred to a firm from abroad or through local diffusion, but the ability to make effective use of it cannot. It should be pointed out that technology and innovation approach offers a more holistic strategy to competitiveness in the developing countries than previous perspectives (Hobday 1995; Kim and Dahlman 1992; Wignaraja 2002a).

A study examining national $R \& D$ projects for technological learning in Korea showed that R\&D plays an important role in indigenous technology capabilities (TCs) building in not only searching for appropriate technology but also absorbing, adapting, and "innovating" the technology (Lee 2004). 
It is postulated that how fast a country actually becomes a core innovator is a function of a complex set of factors that form the national environment of innovation. The environment is captured in the "diamond" framework (see Fig. 1) consisting of four attributes: the presence of high-quality and specialized inputs, a context that encourages investment coupled with intense local rivalry, pressure and insight gleaned from sophisticated local demand, and the local presence of related supporting industries (Porter and Stern 2002).

It is argued that understanding the process of technological diffusion and innovation is critically important for any country that desires to join the group of core innovators. Technology matters in all stages of development and determines a country's competitive advantage, and it is argued that, all things being equal, primary commodity-based economies grew less rapidly in the past few decades than did more-technology-based economies (Porter and Stern 2002).

Kenya only received \$4 million FDI in 1994; similarly, while Kenya's foreign investment was worth only $\$ 42$ million in 1999, it was relatively low compared to other East African countries (Wanjala 2001). FDI has come to swamp all other financial flows and has faced a lot of shifts and instability. Both the flow of foreign aid and FDI do influence Kenya's GDP growth rate with a small margin (Opolot, Mutenyo and Kalio 2009).

East Africa received $\$ 7.8$ billion in FDI in 2015. This was a decrease of $2 \%$ from 2014. FDI flows to Kenya reached a record level of $\$ 1.4$ billion in 2015, which was given impetus by renewed investor interest and confidence in the country's business climate and booming domestic consumer market. Kenya has become a favored business hub, not only for oil and gas exploration but also for manufacturing exports, as well as consumer goods and services. To enhance its investment climate, Kenya has moved to abolish restrictions on foreign shareholding in listed companies, permitting full foreign control, as competition for capital heats up amongst Africa's top capital markets (UNCTAD 2016).

Private investment, both domestic and foreign, is viewed as the driving force of the Kenyan economy (King'ang'i 2003). The main factors influencing investment decisions in third world countries include political risk, economic freedom, business freedom,

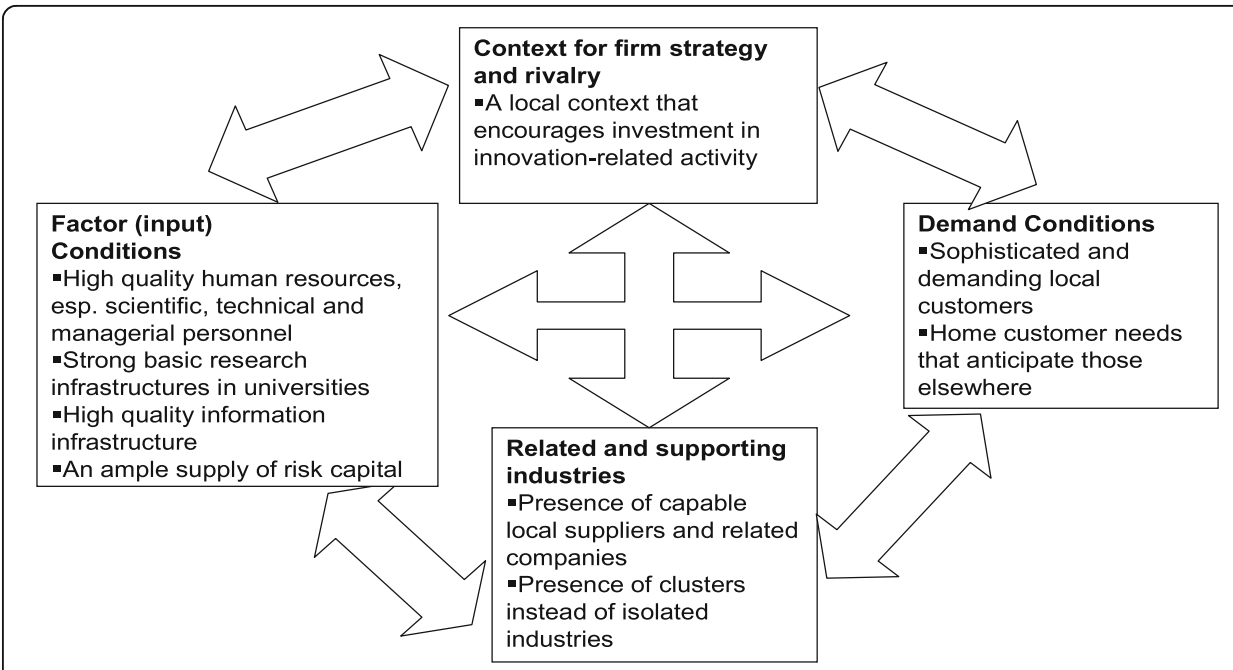

Fig. 1 The national environment for innovation and technological diffusion 
fiscal incentives, trade freedom, government expenditure, inflation, corruption, property rights, state of financial system, and labor regulations (Kayonga 2008). His study points out that policy framework of a country are the most important aspect-these are rules and regulations governing the country and operations of foreign investors. Further, the liberalization of national FDI frameworks in developing economies has been substantially successful in attracting FDIs in those countries. According to a 2007 index of economic freedom assessment, economies that are more open have a better investment environment than liberalized economies (Ngowi 2001).

In the Economic Survey (2008), net FDI flows to developing countries rose from US\$ 367 billion in 2006 to US\$ 471 billion in 2007. This accounted for more than 25\% of global FDI inflows. Of the net FDI flows to developing countries in 2007, Europe and Central Asia accounted for 34\%, while Latin America and the Caribbean and East Asia and Pacific countries accounted for 23 and 25\%, respectively (UNCTAD 2008).

Damooei and Tavakoli (2006) argue that FDI is critical as it provides a major source of capital which brings with it up-to-date technology contributing to economic growth. FDI in services affects the host country's competitiveness by raising the productivity of capital and enabling the host country to attract new capital on favorable terms. In addition, FDI creates services that can be used as strategic inputs in the traditional export sector to expand the volume of trade and to upgrade production through product and process innovation (Todaro 2000). It is argued that FDI improves its competitiveness through technology transfer and the effects of myriad externalities and that foreign as well as domestic investment can alter a country's economic volume and pattern of trade in many income-enhancing directions (Ajayi 2007; Swenson 2004).

The 2000 Millennium Development Goals (MDG) declaration of the United Nations outlines eight commitments to be reached by developing countries by 2015. The achievement of these goals will contribute to human development and economic development. One main source of these capital investments is FDI, since in Kenya and most African countries, the private sector is perceived as an engine of growth in their National Development Strategies. Hence, FDI will play a critical and crucial role in the achievement of these goals or at least in economic growth (World Bank 2004). African countries, with their huge development gaps, need foreign investments to boost their economies in order to lift their populations out of poverty. Over the last decades, FDI to Africa have increased on average in terms of both net inflows FDI per capita and ratio of FDI over total GDP, while at the same time, real per capita GDP and the UNDP-computed HDI were improving (Sharma and Gani 2004).

Foreign firms in Kenya played a major role in enhancing economic growth especially in the agriculture sector, floriculture and horticulture. Gachino and Rasiah (2003) noted that FDI has concentrated on the consumer goods sector, such as food and beverage industries, as well as on other sectors in the economy including services and telecommunication.

The Government of Kenya is focused on sustaining a stable investment climate for private sector participation in energy, developing expanded transmission and distribution networks to deliver power to customers, maintaining a creditworthy off-taker, maintaining cost-reflective tariffs, and reducing inefficiency in the sector to support more affordable end-user tariffs (USAID 2015). 
Kenya Energy Sector Overview the Government of Kenya has set forth its "Vision 2030," a program to transform Kenya into a "newly industrializing, middle-income" country. As of the end of March 2015, Kenya had an installed generation capacity of only $2295 \mathrm{MW}$ or $0.049 \mathrm{~kW}$ per capita (43 million), which constrains economic growth. Although this has grown from an installed capacity base of $1885 \mathrm{MW}$ as of the end of June 2014, it is still very low (see Tables 1 and 2). In FY 2013, it was estimated that $74.5 \%$ of electrical energy was supplied using renewable energy sources, while $25.5 \%$ was generated using fossil fuels. Kenya is believed to possess more than $7000 \mathrm{MW}$ of undeveloped geothermal energy resources in the Rift Valley. Wind and biomass energy are also significant potential sources for power generation. Power Africa is helping Kenya reduce reliance on expensive diesel-fueled generation and other high-cost fossil resources. Kenya aims to increase generation capacity by $5000 \mathrm{MW}$ by 2016 and by 23,000 MW by 2030 (Government of Kenya 2007; USAID 2015).

It is argued that FDI into Kenya has shown significant increase in the last 10 years as companies respond to incentives by investing in Kenya's privatized industries and infrastructure. Kenya's electricity market provides a sound enabling environment for investment. Its attractiveness results from the fact Kenya's energy market offers reasonably independent regulation, cost-reflective tariffs, and a functional market design.

In addition, a history of productive capital investments and sustained regulator and government support for signed PPAs provide a roadmap for future projects. Power Africa, an initiative led by the US Government, which aims to increase the number of people in of sub-Saharan Africa with access to power, is such an FDI initiative that has potential for spurring growth and technology transfer. The aim of Power Africa is to increase electricity access by adding more than 30,000 MW of cleaner, more efficient electricity generation capacity, and 60 million new home and business connections across sub-Saharan Africa including Beyond the Grid sub-initiative, which works to expand rural electrification and access to small scale and off-grid technology. Power Africa awards grants for innovative energy projects across sub-Saharan Africa. In Kenya, Power Africa has already awarded eight $\$ 100,000$ grants for the following project as part of the Power Africa Off-Grid (USAID 2015).

In addition, with a unique private-sector-led model, Power Africa draws on the combined expertise and abilities of 12 US Government agencies, the World Bank Group, the African Development Bank, the Government of Sweden, African governments, and private sector partners. It is expected that with US expertise in energy technology and regulatory reform, combined with US Government and private financial resources, Power Africa will help drive quick-impact interventions and policy reforms to push for

Table 1 Energy demand

\begin{tabular}{llllllllll}
\hline Item & $2005 / 06$ & $2006 / 07$ & $2007 / 08$ & $2008 / 09$ & $2009 / 10$ & $2010 / 11$ & $2011 / 12$ & $2012 / 13$ & $2013 / 14$ \\
\hline $\begin{array}{l}\text { Energy } \\
\text { generated } \\
\text { (GWh) }\end{array}$ & 5697 & 6169 & 6385 & 6489 & 6692 & 7303 & 7670 & 8807 & 8840 \\
$\begin{array}{l}\text { Energy sold } \\
\text { (GWh) }\end{array}$ & 4580 & 5065 & 5322 & 5432 & 5624 & 6123 & 6341 & 6581 & 7244 \\
$\begin{array}{l}\text { Peak demand } \\
\text { (MW) }\end{array}$ & 920 & 987 & 1044 & 1072 & 1107 & 1194 & 1236 & 1357 & 1468 \\
$\begin{array}{l}\text { Number of } \\
\text { customers }\end{array}$ & 802,249 & 924,329 & $1,060,383$ & $1,267,198$ & $1,463,639$ & $1,753,348$ & $2,038,625$ & $2,330,962$ & $2,766,441$ \\
\hline
\end{tabular}


Table 2 Energy generated and corresponding capacity as of June 2014

\begin{tabular}{|c|c|c|c|c|c|}
\hline \multicolumn{2}{|c|}{ Sources of power generation } & \multicolumn{2}{|c|}{ Installed capacity (KP, 6/14) } & \multicolumn{2}{|c|}{ Annual generation } \\
\hline Renewable energy & Hydro & $\begin{array}{l}(\mathrm{MW}) \\
817\end{array}$ & $\begin{array}{l}\text { Percentage } \\
43\end{array}$ & $\frac{(G W h)}{3944}$ & $\begin{array}{l}\text { Percentage } \\
45\end{array}$ \\
\hline & Thermal & 264 & 14 & 817 & 9 \\
\hline & Geothermal & 253 & 13 & 1156 & 13 \\
\hline & Wind & 5.3 & 0.3 & 17.6 & 0.2 \\
\hline & Imports & & & 87 & 1 \\
\hline & Total & 1340 & 71 & 6025 & 68 \\
\hline \multirow[t]{4}{*}{ Fossil fuel } & IPP & 497 & 26 & 2698 & 31 \\
\hline & Off-grid & 19 & 1 & 31 & 0.4 \\
\hline & Emergency & 30 & 2 & 93.8 & 1 \\
\hline & Total & 546 & 29 & 2061 & 32 \\
\hline \multicolumn{2}{|c|}{$\begin{array}{l}\text { Installed capacity and } \\
\text { units generated }\end{array}$} & \multicolumn{2}{|c|}{$1885 \mathrm{MW}$} & \multicolumn{2}{|c|}{$1840 \mathrm{GWh}$} \\
\hline
\end{tabular}

sustainable energy development. This is therefore an FDI initiative that has contribution to technology transfer. Further, Power Africa has to date leveraged more than \$20 billion in commitments from the private sector for new on- and off-grid projects in Sub-Saharan Africa. The US Government's commitments include the provision of more than $\$ 7$ billion in financial support, loan guarantees, and technical support, with every dollar committed to Power Africa by US Government leveraging almost three dollars in private investment commitments. Together with this, the African Development Bank, the World Bank Group, and the Swedish Government have collectively committed an additional $\$ 9$ billion in support of Power Africa (USAID 2015).

According to Power Africa update (2015, July), the USA is supporting the development of the energy sector through financing, grants, technical assistance, and investment promotion. Power Africa is working to mobilize more than $\$ 1$ billion in private investment for electricity to accelerate geothermal and wind projects. Central to the work of Power Africa/Kenya is the Grid Management Support Program (GMSP). GMSP is providing technical assistance to address key challenges of integrating intermittent renewable energy into the national grid (USAID 2015).

\section{Infrastructure}

Froot and Jeremy (1991) examine whether hard infrastructure, in the form of more highways and railroads, or soft infrastructure, in the form of more transparent institutions and deeper reforms, leads to more FDI. Soft infrastructure is a more important determinant of FDI than hard infrastructure. Grossman and Helpman (2002) examine the effect of government infrastructure on both the probability that a country receives FDI and separately on the amount of FDI received (for countries receiving any FDI). They find that countries failing to achieve a minimum threshold of effective governance are unlikely to receive any US FDI.

More FDI is likely to occur in countries with good physical infrastructure such as bridges, ports, and highways. It also seems likely that there are some diminishing returns in infrastructure, at least in infrastructure of a specified type and especially for countries with poor infrastructure, and investing in improvements in infrastructure 
may be important for attracting FDI. Nonetheless, some countries with poor infrastructure may be unattractive hosts for FDI for a variety of other reasons, and even substantial investments in infrastructure might not bring FDI pouring in. But all else equal, a country with better infrastructure would be expected to attract more FDI (Marwah and Tavakoli 2004)

The positive effect of infrastructure on FDI has been found to be quite robust to time periods and countries considered, other control variables included, and the like. Examining the determinants of FDI into the USA for 1981-1983, Coughlin et al. (1991) found that more extensive transportation infrastructures were associated with increased FDI.

\section{Technology diffusion and knowledge transfer}

Technology is seen as a key determinant of productivity. However, given the fact that a small number of rich countries account for most of the world's creation of new technology, there is now widespread recognition that the international transfer of technology is an important source of domestic productivity growth and ultimately higher living standards (Rasiah and Gachino 2005). New technology might on the other hand also decrease demand for labor by substituting large number of low-skilled employees with fewer high-skilled employees or by substituting capital for labor. Hence, technology policies will affect the degree of job creation.

Domestic firms' technological gain from FDI generally results from two channels. First, there are a number of channels through which FDI affects productivity of domestic firms. In the first, spillovers through demonstration effect take place when a domestic firm improves its productivity by simply observing nearby foreign firms and copying some technology. Second, another type of spillovers is through competition between foreign firms and domestic firms. FDI may toughen the competition faced by domestic firms, thereby forcing them to become more competitive (UNCTAD 2008). On the other hand, increased competition with inward FDI can also reduce productivity of domestically owned firms, particularly in the short run. If imperfectly competitive firms have to incur fixed costs of production, a foreign firm with lower marginal costs will have an incentive to increase production relative to its domestic competitor. In this environment, entering foreign firms producing for the domestic market can steal demand from domestic firms, forcing them to reduce production (Ngowi 2001). In terms of the first channel, this can be achieved directly through licensing or indirectly through foreign direct investment (FDI). International knowledge flows raise growth in both models.

\section{Growth of domestic firms through complimentary production and production spillovers}

Spillover effects are indirect effects of inward FDI and are here defined as the unintended transmission of knowledge and skills from the FDI enterprise to domestic enterprises via demonstration effects and/or worker mobility. As external effects of the FDI enterprise's activity, they are not priced. It is generally assumed that foreign investors produce at a higher level of technology than local firms and therefore can stimulate such effects through technology transfer from more advanced countries to developing countries (FAO 2001). Spillovers also depend on the difference in the level of technological intensity between MNEs and local firms and the degree of exportorientation of the FDI (Hansen and Rand 2006). This has implications for the desired type of FDI. FDI featuring a slightly higher technology level than domestic firms 
might be more desirable than high-technology FDI which cannot establish relations to the domestic economy. Export-oriented FDI tends to generate more employment and facilitates better access to the global economy via market access/export spillovers (Gachino and Rasiah 2003). Similarly, foreign firms that operate in isolation with little linkages to domestic enterprises are less likely to generate a lot of spillovers to local firms.

Regarding the motivation of the investment, market-seeking FDI in developing countries facilitates more linkages than investment for other purposes. One reason is that affiliates which produce for the domestic market often have more freedom to choose suppliers than affiliates fulfilling their role in the international production system of their parent company (UNCTAD 2001). Other factors relate to the size of the affiliate and the role assigned to the foreign affiliate. In a study of the Irish electronics industry, Görg and Ruane (2000) found that small affiliates have stronger linkages than large ones. It was further found that affiliates with greater autonomy have stronger linkages in the electronics and garment industry in Africa (Görg and Ruane 2000).

The occurrence of these direct and indirect effects and linkages has been extensively examined for FDI from industrialized countries to developing countries. For developing source countries, in contrast, rigorous empirical assessment of the development effects is to date scarce, and results are expected to contrast. It is argued that FDI is more beneficial for host country development based on theoretical considerations of the "technology gap" and greater labor intensity of this type of investment (UNCTAD 2008).

\section{Facilitation of trade and access to export markets}

FDI in an industry may create a market for local firms which can either be in the same industry or in different industries. Investment and desired output are functions of many variables that influence firm profitability, some of which are inevitably omitted from any empirical analysis, and these omissions may themselves induce positive or negative correlations between foreign and domestic activities (O'Brien and Ryan 2001).

Since the locations of foreign investments differ significantly between firms, it is possible to construct firm-specific weighted averages of foreign GDP growth. These firm-specific foreign economic growth rates can be used to generate predicted growth rates of foreign activity that are then employed to explain changes in domestic activity (Hansen and Rand 2006). There are several channels through which foreign activities can influence the scope of domestic operations, including cases in which foreign production requires inputs of tangible or intellectual property produced in the home country. The same instrumental variable method used to identify the effect of foreign investment on domestic investment can also be used to identify the effect of foreign investment on other types of domestic activity. The use of weighted foreign economic growth rates as instruments for changes in foreign investment has the potential to produce misleading results if the foreign investments of firms planning rapid expansion of domestic investment are disproportionately attracted to economies expected to grow rapidly (Hanson et al. 2001).

The effect of foreign operations on the domestic activities of multinational firms therefore remains an open question (Blonigen 1997). Much of the recent theoretical and empirical work on multinational firms emphasizes alternative motivations for 
foreign direct investment or the reasons why alternative productive arrangements are employed, the importance of vertical specialization to international trade patterns and the expansion strategies of multinational firms. The findings of this research that multinational firms exhibit high degrees of integrated production are consistent with sizeable effects of foreign operations on domestic activity (Hubert and Nigel 2000).

\section{Knowledge management}

There are a variety of ways in which globalization affects labor: the most important ones are through increased trade, FDI, and international technology transfer. FDI can also lead to increased employment amongst local firms as a result of backward or forward linkages so that the direct employment by foreign affiliates may underestimate the total impact. There may also be spillovers to domestic firms as a result of training by foreign investors or technology transfer. Foreign firms that are subject to pressures in their home countries may also bring with them higher labor standards and wages than the norm for the host economy (Mwega and Ngugi 2007).

Not only the direct employment effects of FDI in developing countries have been unsubstantial but also the indirect effects have been minimal and possibly even negative. The outcome in terms of indirect effects depends on the balance between the crowding-in effects of FDI creating new markets for local investors and the crowdingout affects that arise when foreign affiliates displace local competitors. Foreign investors in developing economies have created very limited local linkages since they import most of their inputs (Rasiah and Gachino 2005).

\section{Conceptual framework}

A conceptual framework that was used in research to outline possible courses of action is presented in Fig. 2. The FDI aspects (independent variables) of infrastructure development, technology diffusion and knowledge management, facilitation of trade and access to export markets and enhancing employment, and skills and management techniques and the influence they have on economy growth (dependent variable) as related to the energy sector are considered in the conceptual framework. Technological progress is critical to economic growth and welfare for any country, regardless of the level of development. Special attention is given to the role of technology

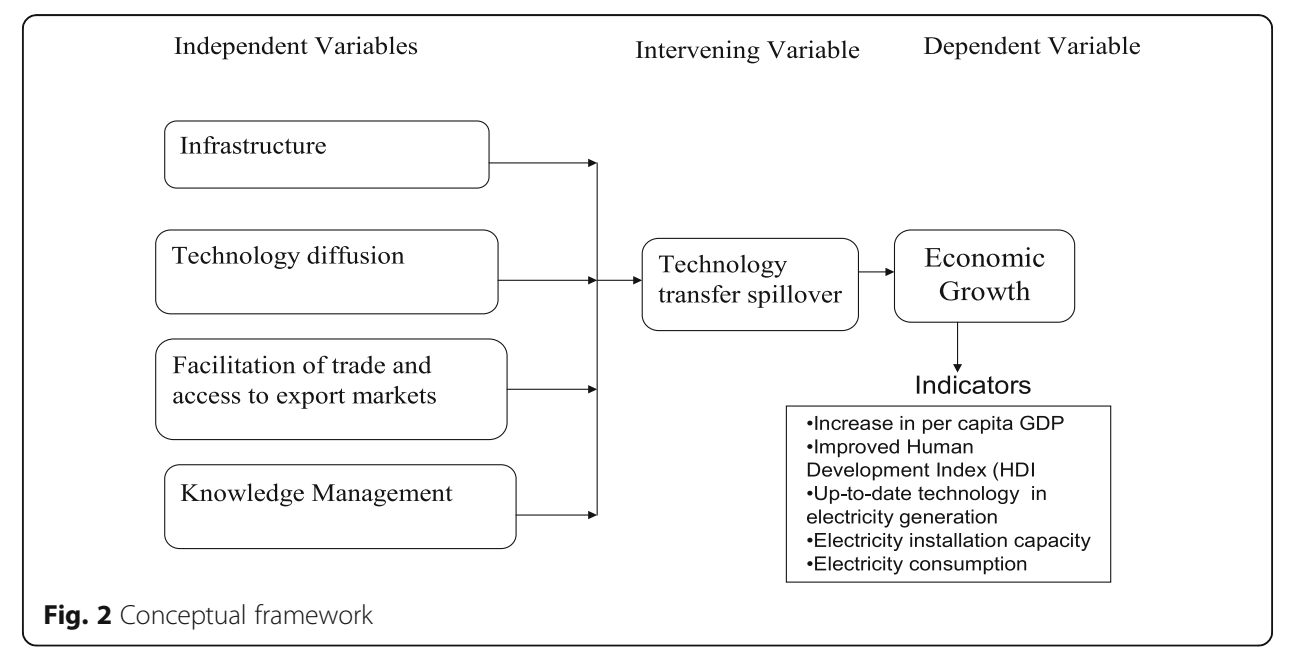


transfer and diffusion in building productive, adaptive, and technological capacities and enhancing human resources in developing countries, in particular LDCs or lowincome countries (UNCTAD 2010).

\section{Methods}

This study adopted a descriptive and inferential survey design. Descriptive studies portray the variables by answering who, what, and how questions (Babbie 1998). The aim of this study was to determine a cause-and-effect relationship between effects of foreign direct investment on the growth of the economy in Kenya. Data was analyzed to estimate the result of the correlation $(r)$ between the independent variables and the dependent variable and also multiple regression analysis to establish the strength of those relationships between the variables. The target population for this study was the directors and managers from Kenya Power and Kengen. Since the population of the study was small, the study involved all the respondents $100 \%$ to have a census survey of 60 respondents (see Table 3).

Primary data was collected using semi-structured questionnaires. Secondary data was collected through documentary analysis on effects of foreign directs investment in the energy sector on economic growth in Kenya between the years 2001 to 2011. The study questionnaire was developed based on the study objectives, and then the questionnaire was tested for validity. This was achieved by pre-testing the instrument that was used to identify and change any ambiguous, awkward, or offensive questions and technique as emphasized by Cooper and Schindler (2008). In this study, reliability was ensured by using the internal consistency test to measure the extent to which the items in questionnaire reflected the concepts or variables for the study. Accordingly, Cronbach's alpha of 0.6 and above were considered acceptable (Cooper and Schindler 2008).

Correlation and multiple regression analysis were used to evaluate the degree of relationship between the FDI and economic growth. Multiple regression analysis was used to determine the relationship between the independent and dependent variable to predict the score of the dependent variable from the independent variables. A multivariate regression model was applied to establish the effects of foreign direct investment on the economic growth in Kenya.

$$
Y=\alpha+\beta_{1} X_{1}+\beta_{2} X_{2}+\beta_{3} X_{3}-\beta_{4} X_{4+\ddot{e}}
$$

$\alpha$ is the constant and $\beta_{1}, \beta_{2}, \beta_{3}$ and $\beta_{4}$ were the coefficients of the independent variables while $e$ is the standard error. $X_{1}, X_{2}, X_{3}$, and $X_{4}$ represents the foreign direct investment issues such as infrastructure, technological diffusion, facilitation of trade, and increase in export markets and inflow of knowledge management.

Table 3 Sampling frame

\begin{tabular}{llll}
\hline Category & $\begin{array}{l}\text { Population } \\
\text { Equally distributed amongst } \\
\text { Kenya Power and Kengen }\end{array}$ & Sample proportion (\%) & Sample size \\
\hline Directors & 10 & 100 & 10 \\
Managers & 20 & 100 & 20 \\
Chief finance officer & 30 & 100 & 30 \\
Total & 60 & & 60 \\
\hline
\end{tabular}




\section{Results}

This section discusses the interpretations and presentations of the findings based on the research objective which was to establish the effect of FDI on economic growth in Kenya focusing on the energy sector between 2001 and 2011. Specific objectives were to establish the effects of infrastructures on economic growth in Kenya, to find out the contribution of the technology diffusion on economic growth in Kenya, to assess the contribution of the trade on economic growth in Kenya, and to determine the contribution of the knowledge management on economic growth in Kenya. The operational hypotheses in relation to FDI which were tested are also shown. Thus, in Ho1, there is no functional relationship between infrastructure and economic growth; in Ho2, there is no functional relationship between technology diffusion and economic growth; in Ho3, there is no functional relationship between facilitation of trade and access to export markets and economic growth; and in Ho4, there is no functional relationship between knowledge management and economic growth.

\section{Response rate}

The sample population was 60 respondents out of which 60 respondents completed and returned the questionnaires. This constituted a $100 \%$ response rate. The researcher administered the questionnaire with the help of the research assistants and hence the high rate of respondent's rate.

\section{Reliability tests}

The study used internal consistency reliability test to find out the extent the measures indicative of the homogeneity of the items in measure that taps the construct. In this regard, Cronbach's alpha as a reliability coefficient that indicates how well the items in a set are positively correlated to one another was computed (Sekaran and Bougie 2013). Table 4 provides an overview of Cronbach's alpha for the four variables. The table shows that the alphas were all well above 0.60. The relevant Cronbach's coefficients were as follows: infrastructure, 0.7527; technology diffusion, 0.8892; facilitation of trade and access to export markets, 0.8049; and knowledge management, 0.8350. The overall Cronbach's alpha was 0.8350 which is considered good (Sekaran and Bougie 2013).

\section{Pearson's correlations analysis}

The Pearson correlation matrix which indicates the direction, strength, and significance of the relationships between independent and dependent variables was computed. Table 5 shows the correlation analysis of the variables.

Table 4 Reliability statistics

\begin{tabular}{lcc}
\hline Variable & Cronbach & No. of item \\
\hline Infrastructure & 0.7527 & 6 \\
Technology diffusion & 0.8892 & 6 \\
Facilitation of trade and access to export markets & 0.8049 & 6 \\
Knowledge management & 0.8350 & 6 \\
Overall & 0.8327 & 6 \\
\hline
\end{tabular}


Table 5 Pearson correlation analysis

\begin{tabular}{lllll}
\hline & & Infrastructure & Technology diffusion & $\begin{array}{l}\text { Knowledge } \\
\text { management }\end{array}$ \\
\hline Infrastructure & Pearson correlation & 1 & & \\
& Sig. (2-tailed) & 0.02 & & \\
Technology diffusion & $N$ & 60 & & \\
& Pearson correlation & $0.768^{* *}$ & 1 & \\
& Sig. (2-tailed) & 0.001 & & 1 \\
Facilitation of trade & $N$ & 60 & 60 & 60 \\
& Pearson correlation & $0.0 .839^{* *}$ & $0.590^{* *}$ & 430 \\
& Sig. (2-tailed) & 0.001 & 0.007 & 0.003 \\
Knowledge management & $N$ & 60 & 60 & 60 \\
& Pearson correlation & $0.835^{* *}$ & $0.580^{*}$ & $489^{*}$ \\
& Sig. (2-tailed) & 0.002 & 0.037 & 0.0311 \\
& $N$ & 60 & 60 & 60 \\
\hline
\end{tabular}

${ }^{* *}$ Correlation is significant at the 0.01 level (2-tailed); ${ }^{*}$ correlation is significant at the 0.05 level (2-tailed)

Table 5 shows that there is a significant correlation $(r)$ between FDI in infrastructure (0.856, sig. at the 0.01 level (two-tailed)) and the economic growth in the energy sector. In addition, there is an association between technology diffusion $(r=0.768$ sig. at the 0.01 level (two-tailed)) and infrastructure and hence economic growth in the energy sector.

Further, there is a positive correlation between facilitation of trade and FDI in infrastructure and hence economic growth in the energy sector $(r=0.839$ and a significance level of $p<0.01$ ). In addition, there is a positive correlation between facilitation of trade and technology diffusion and hence economic growth in energy.

Lastly, there is a positive correlation between knowledge management (correlation coefficient of 0.856 with a $p$ less than 0.05 ) and FDI in infrastructure and hence economic growth in the energy sector. In addition, there is an association between knowledge management $(r=0.739$, significant at $p$, less than 0.005) and technology diffusion and hence economic growth in the energy sector.

\section{Regression analysis}

Multiple regression analysis was used as the study hypothesized that the independent variables affected the dependent variable or explained the variance in the dependent variable (see Tables 6,7 , and 8). Thus, multiple regression analysis provides a means of

Table 6 Model summary

\begin{tabular}{|c|c|c|c|c|c|c|c|c|c|}
\hline \multirow[t]{2}{*}{ Model } & \multirow[t]{2}{*}{$R$} & \multirow[t]{2}{*}{$R^{2}$} & \multirow{2}{*}{$\begin{array}{l}\text { Adjusted } \\
R \text {-square }\end{array}$} & \multirow{2}{*}{$\begin{array}{l}\text { Std. error of } \\
\text { the estimate }\end{array}$} & \multicolumn{5}{|l|}{ Change statistics } \\
\hline & & & & & $R$-square change & F change & $d f 1$ & $d f 2$ & Sig. F change \\
\hline 1 & $0.82^{\mathrm{a}}$ & 0.672 & 0.671 & 0.34 & 1.741 & 6 & 6.207 & 8.191 & $0.001^{a}$ \\
\hline
\end{tabular}


Table 7 ANOVA

\begin{tabular}{llcllll}
\hline Model & & Sum of squares & Df & Mean square & $F$ & Sig. \\
\hline 1 & Regression & 3.841 & 6 & 0.307 & 5.191 & $0.01^{\text {a }}$ \\
& Residual & 7.714 & 54 & 0.059 & & \\
& Total & 11.556 & 60 & & & \\
\hline
\end{tabular}

Dependent: economic growth

apredictors: (Constant) as infrastructure, technological diffusion, facilitation of trade and increase in export markets, and knowledge management

assessing the degree and the character of the relationship between the independent variables and the dependent variable; the regression coefficients indicate the relative importance of each of the independent variables in the prediction of the dependent variable (Sekaran and Bougie 2013).

Table 6 shows an adjusted $R$-square of 0.671 . This means that the model explains $67.1 \%$ of the variance in the dependent variable, economic growth. Thus, the independent variables are good predictors of the dependent variable, economic growth. The findings were statistically significant with $p<0.01$.

The significance of the regression model is tested with an $F$-statistic. The summarized result is shown in Table 7 . The hypotheses are as follows: H0: the regression model does not explain a significant proportion of the variation in the economic growth and Ha: the regression model explains a significant proportion of the variation in economic growth. The regression $F$ test results $(F=5.191)$ is significant at $p<0.01$. Therefore, the null hypothesis is rejected. Thus, there is support that the regression model explains the dependent variable, economic growth.

The regression coefficient, which explains the contribution of the independent variables to the regression equation, and the dependent variable, economic growth, are shown in Table 8 . The population regression coefficient $(\beta)$ is 0.768 and is significant. That is, it is significantly different from zero, and it implies that all independent variables are playing a useful role in the regression model. The standardized beta $(\beta)$ for infrastructure, technology diffusion, trade facilitation, and knowledge management are all significant at $p<0.01$. Thus, these four variables have a significant contribution to the economic growth.

\section{Discussion}

This section provides the summary of the findings, conclusions, and recommendations for study.

Table 8 Coefficients

\begin{tabular}{|c|c|c|c|c|c|c|}
\hline \multirow[t]{2}{*}{ Model } & & \multicolumn{2}{|c|}{ Unstandardized coefficients } & \multirow{2}{*}{$\begin{array}{l}\text { Standardized coefficients } \\
\text { Beta }\end{array}$} & \multirow[t]{2}{*}{$t$} & \multirow[t]{2}{*}{ Sig. } \\
\hline & & $B$ & Std. error & & & \\
\hline \multirow[t]{5}{*}{1} & (Constant) & 0.768 & 0.275 & & 3.640 & 0.01 \\
\hline & Infrastructure & 0.881 & 0.405 & 0.857 & 2.931 & 0.001 \\
\hline & Technology diffusion & 0.717 & 0.546 & 0.722 & 2.803 & 0.04 \\
\hline & Facilitation of trade & 0.568 & 0.520 & 0.791 & 1.906 & 0.007 \\
\hline & Knowledge management & 0.791 & 0.690 & 0.729 & 1.672 & 0.01 \\
\hline
\end{tabular}

Predictors: (Constant) as infrastructure, technological diffusion, facilitation of trade, and knowledge management. Dependent: economic growth 


\section{Discussion of findings}

Correlation analysis (Table 5 ) shows that there is a positive correlation $(r)$ between FDI in infrastructure $(0.856$, sig. at the 0.01 level (two-tailed)) and economic growth. In addition, there is an association between technology diffusion ( $r=0.768 \mathrm{sig}$. at the 0.01 level (two-tailed)) and infrastructure and hence economic growth. Further, there is a positive correlation between facilitation of trade and FDI in infrastructure and hence economic growth $(r=0.839$ and a significance level of $p<0.01)$. In addition, there is a positive correlation between facilitation of trade and technology diffusion and hence economic growth. Lastly, there a positive correlation between knowledge management (correlation coefficient of 0.856 with a $p$ less than 0.05) and FDI in infrastructure and hence economic growth. In addition, there is an association between knowledge management ( $r=0.739$, significant at $p$, less than 0.005$)$ and technology diffusion and hence economic growth.

The findings from the study also show that the independent variables infrastructure, technology diffusion, trade facilitation, and knowledge management explain $67.1 \%$ of the change in economic growth. This is in line with the studies by Zhang (2001) who found that there existed a positive relationship between FDI and economic growth.

The findings also concur with Damooei and Tavakoli (2006) who found that FDI was critical as it provides a major source of capital which brings with it up-to-date technology contributing to economic growth. It is contended that foreign investors in the energy sector influence the organizational skills, increase the accessibility to the foreign markets through channels for marketing products, increase employment opportunities, and improve standards of living consistent with the foreign enterprises' commercial objectives. However, it is argued that a high share of FDI in a country's total capital inflows may reflect its institutions' weakness rather than their strength (King'ang'i 2003).

In line with the findings of the study, it is argued that spillover effects are indirect effects of inward FDI and are here defined as the unintended transmission of knowledge and skills from the FDI enterprise to domestic enterprises via demonstration effects and/or worker mobility. It is generally assumed that foreign investors produce a higher level of technology than local firms and therefore can stimulate such effects. Spillovers also depend on the difference in the level of technological intensity between MNEs and local firms and the degree of export-orientation of the FDI. Similarly, foreign firms that operate in isolation with little linkages to domestic enterprises are less likely to generate a lot of spillovers to local firms (FAO 2001; Hansen and Rand 2006; Gachino and Rasiah 2003; UNCTAD 2001; Görg and Ruane 2000).

In addition, the research findings show that there is a relationship between knowledge management and technology diffusion and infrastructure development and hence economic growth. This finding is in line with the argument that collaboration with other firms and institutions in R\&D offer possibilities for knowledge transfer, resource exchange, and organizational learning (Becker and Dietz 2004; Koschatzky et al. 2001; Plunket et al. 2001; OECD 2010; Young et al. 1989).

The findings underscore the spillover effect resulting from technology transfer. Domestic firms' technological gain from FDI generally results from two channels. First, there are a number of channels through which FDI affects productivity of domestic firms. In the first, spillovers through demonstration effect take place when a domestic 
firm improves its productivity by simply observing nearby foreign firms and copying some technology. Second, another type of spillovers is through competition between foreign firms and domestic firms. FDI may toughen the competition faced by domestic firms, thereby forcing them to become more competitive (UNCTAD 2008).

The findings show that there is relationship between facilitation of trade and infrastructure development and technology diffusion. This is line with the argument that the motivation for FDI is to gain access to expertise or attributes (innovative and entrepreneurial skills) possessed by partner enterprises, achievement of economies of scale or pooling of $\mathrm{R} \& \mathrm{D}$, risk reduction shaping competition (including collusion to raise market entry barriers, fix prices, etc.), and diversification to enable the larger companies to stay at the leading edge of research on the wide variety of technical fronts. The motivations by foreign firms' FDI also tend to enable technology diffusion by domestic firms (Young et al. 1989).

FDI in the energy sector has led to efficient procuring networks for production and sales of local goods internationally, transferring technologies and establishing markets for domestic production, increased domestic savings, and improved investment policies. In addition, it has led to attraction of new capital on favorable terms to the country, reduction of net debt flows, influencing the establishment of finance-related and trading networks upgrading of telecommunications services in Kenya, and also led to industrial upgrading in the country. Through the major investment in the energy sector, local firms use new technologies to increase their productivity and thus contribute to economic growth. However, most of the potential costs and benefits of foreign capital result from more indirect effects of FDI either through the transfer of skills and technologies.

\section{Conclusions}

It can be concluded that foreign direct investment may promote economic development by contributing to productivity growth and exports in the host countries. However, the exact nature of the relation between foreign direct investment and the host economies vary between industries and countries. It is reasonable to assume that the characteristics of the host country's industry and policy environment are important determinants of the net benefits of FDI which include industrial growth, improved technology, and infrastructure in the country.

It is contended that FDI not only provides the countries with much needed capital for domestic investment but also creates employment opportunities and helps transfer of managerial skills and technology, all of which contribute to economic development. Thus, there is recognition for the need to foster a favorable climate for attracting FDI in order to contribute economic development. Indeed, the world market for such investment is highly competitive. Consequently, Kenya government should pay more attention to the measures that actively facilitate FDI. The distinctive combination of advantages and created assets that Kenya can offer potential investor remain very important economic determinants. A major implication of this study is that policy makers must devise policies that would create conducive environment to attract FDIs.

The main objective of this study was to investigate the role of foreign direct investment on technology transfer and economic growth in Kenya. This study has not 
explicitly dealt with questions related to host country policies on foreign direct investment hence the findings of the study highlight the need for future research in this area. Empirical literature indicates that infrastructure, technological diffusion, facilitation of trade, and knowledge management elements of FDI have an effect on technology transfer and hence economic growth. The study suggests that an appropriate proxy for these variables be identified and measured to further develop on this research.

The main limitation of the study was that more sectors across Kenya were not covered which would have facilitated comparative and a more broad-based analysis. Further, the study was not carried across all the stakeholders in the energy sectors to enable generalization of the study findings.

\section{Authors' contributions}

The corresponding author (HMO) has written the article. The co-author (PWK) has contributed in the collection, analysis, and interpretation of the results. Both authors read and approved the final manuscript.

\section{Competing interest}

The authors declare that they have no competing interests.

\section{Author details}

${ }^{1}$ Strategic Initiatives Consulting, P.O. Box 5258600200 Nairobi, Kenya. ${ }^{2}$ Africa Nazarene University, P.O. Box 5306700200 Nairobi, Kenya.

Received: 29 April 2016 Accepted: 2 November 2016

Published online: 29 November 2016

\section{References}

Abor, J., Charles, K., Adjasi, D., \& Hayford, M. (2008). How does foreign direct investment affect the export decisions of firms in Ghana? African Development Bank. Oxford: Blackwell Publishing Ltd.

Aghion, P., \& Howitt, P. (1992). A model of growth through creative destruction. Econometrica, 60, 323-51.

Aghion, P., \& Howitt, P. (1998). Endogenous growth theory. Cambridge: MIT Press.

Ajayi, S. I. (2007). Foreign direct investment in Sub-Saharan Africa: origins, targets, impact and potential Africa. Nairobi: African Economic Research Consortium.

Babbie, E. (1998). The practice of social research. Wadsworth: Thomson Learning.

Becker, W., \& Dietz, J. (2004). R\&D cooperation and innovation activities of firms: evidence for the Germany manufacturing industry. Research Policy, 33, 209-223.

Blonigen, B., A. (1997). Firm-specific assets and the link between exchange rates and foreign direct investment. American Economic Review, 87(3), 447-65.

Bodman, P., \& Le, T. (2013). Assessing the roles that absorptive capacity and economic distance play in the foreign direct investment-productivity growth nexus. Applied Economics, 2013(45), 1027-1039.

Chen, S. H. (2002). Global production networks and information technology: the case of Taiwan. Industry and Innovation, 9(3), 247-264.

Chen, S. H. (2004). Taiwanese IT firms' offshore R\&D in China and the connection with the global innovation network. Research Policy, 33, 337-349.

Chen, T.-J. (2003). Network resources for internationalization: the case of Taiwan's electronics firms. Journal of Management Studies, 40(5), 1107-1130.

Chia, S. Y. (1993). "Foreign direct investment in ASEAN economies". Asian development review (pp. 60-102).

Chia, S. Y. (1997). Singapore: advanced production base and smart hub of the electronics industry. In W. Dobson \& S. Y. Chia (Eds.), Multinationals and East Asian Integration (pp. 31-61). Canada and Singapore: International Development Research Centre, Canada and Institute of Southeast Asian Studies.

Coe, D., \& Helpman, E. (1995). International R\&D spillovers. European Economic Review, 39, 859-87.

Coe, D., Helpman, E., \& Hoffmaister, A. (1997). North-South R\&D spillovers. The Economic Journal, 107, 134-49.

Cooper, D., \& Schindler, P. (2008). Business research methods. New York: McGraw-Hill.

Coughlin, C. C. Terza J. V. \& Arromdee, V. (1991). "States Characteristics and the Location of Foreign Direct Investment within the United States", Review of Economics and Statistics, Vol. 73, No. 4, pp. 675-683. doi:10.2307/2109406.

Damooei, J., \& Tavakoli, A. (2006). The effects of foreign direct investment and imports on economic growth: a comparative analysis of Thailand and The Philippines. Journal of Developing Areas, 39(2), 79-100.

Durham, B. (2004). Absorptive capacity and the effects of FDI and equity foreign portfolio investment on economic growth. European Economic Review, 48, 285-306.

FAO (2001). Agricultural investment and productivity in developing countries. Economic and Social Development Paper, Vol. 148, pp. 55-74.

Findlay, R. (1978). Some aspects of technology transfer and direct foreign investment. American economic review, american economic association, Vol. 68, No. 2, pp. 275-79.

Froot, K. A., \& Jeremy, C. S. (1991). Exchange rates and foreign direct investment: an imperfect capital markets approach. Quarterly Journal of Economics, 106(4), 1191-1217.

Gachino, G., \& Rasiah, R. (2003). Labour productivity, exports and skills formation: comparing foreign and local firms in Kenyan Manufacturing Industry. Paper presented at the International Workshop (pp. 22-24). Oslo: FDI-Assisted Development. 
Görg, H., \& Ruane, F. (2000). An analysis of backward linkages in the Irish electronics sector. Economic and Social Review, 31, 215-235.

Government of Kenya. (2007). Vision 2030, Ministry of Planning and National Development. Nairobi: The Government Printer.

Graham, E. M. (1995). "Foreign Direct Investment in the World Economy". IMF World Economic and Financial Survey, pp. 120-135. Washington: IMF.

Griffin, R. W., \& Pustay, M. W. (2002). International business: a managerial perspective. London: Pearson Education.

Grossman, G. M., \& Helpman, E. (2002). Integration versus outsourcing in industry equilibrium. Quarterly Journal of Economics, $117,85-120$.

Grossman, G., \& Helpman, E. (1991). Innovation and growth in the global economy. Cambridge: The MIT Press.

Hansen, H., \& Rand, J. (2006). On the causal links between FDI and growth in developing countries. World Economy, 29(1), 21-41. United Nations University.

Hanson, G. H., Mataloni, R. J., \& Slaughter, M. J. (2001). Expansion strategies of U.S. multinational firms. Cambridge: NBER Working Paper 8433 National Bureau of Economic Research.

Hobday, M. (1995). Innovation in East Asia: the challenge to Japan. UK: Edward Elgar, Aldershot.

Hubert, F., \& Nigel, P. (2000). Inward investment and technical progress in the United Kingdom. Glasgow: University of Strathclyde, Department of Economics.

Kayonga, G. W. (2008). A comparative study of foreign direct investment policy in Eastern Africa: the case of Rwanda and Tanzania (2000-2006) thesis (M.A.). Nairobi: University of Nairobi.

Kakazu, H. (1990). "Industrial technology capabilities and policies in selected Asian developing countries (with particular emphasis on transferred technology)", Asian Development Bank Economic Staff Paper No. 46. Manila: Asian Development Bank.

Kim, L., \& Dahlman, C. J. (1992). Technology policy for industrialization: integrative framework and Korea's experience. Research Policy, 21, 437-452.

King'ang'i, P. K. (2003). Private investment and economic growth in Kenya. An empirical investigation: 1980-2002, thesis (M. A.). Nairobi: University of Nairobi.

Klein, M. W., \& Rosengren, E. S. (1994). The real exchange rate and foreign direct investment in the United States: relative wealth vs. relative wage effects. Journal of International Economics, 36(3-4), 373-89.

Koschatzky, K., Kulicke, M., \& Zenker, A. (2001). Innovation networks, concepts and challenges in the European Perspectives. Technology, innovation, and policy (Vol. 12). Heidelberg: Physica-Verlag.

Kwark, N., \& Shyn, Y. (2006). International R\&D spillovers revisited: human capital as an absorptive capacity for foreign technology. International Economic Journal, 20, 179-96.

Le, T. (2008). Brain drain or brain circulation: evidence from OECD's international migration and R\&D spillovers. Scottish Journal of Political Economy, 55, 618-36.

Le, T., \& Bodman, P. (2011). Remittances or technological diffusion: which drives domestic gains from brain drain? Applied Economics, 43, 2277-85.

Le, H. Q., \& Pomfret, R. (2011). Technology spillovers from foreign direct investment in Vietnam: horizontal or vertical spillovers? Journal of the Asia Pacific Economy, 16(2), 183-201.

Lee, T. J. (2004). Technological learning by national R\&D: the case of Korea in CANDU-type nuclear fuel. Technovation, 24, 287-297.

Managi, S., \& Bwalya, S. M. (2010). Foreign direct investment and technology spillovers in sub-Saharan Africa. Applied Economics Letters, 17, 605-608.

Marwah, K., \& Tavakoli, A. (2004). The effects of foreign capital and imports on economic growth. Journal of Asian Economics, 15, 399-413.

Mathews, J. A. (2005). Dragon multinationals: new players in 21st century globalization, MGSM WP 2005-15. Sydney: Macquarie Graduate School of Management.

Melitz, M., \& Gianmarco, O. (2008). Market size, trade, and productivity. Review of Economic Studies, 75, 295-316.

Modarress, B., Ansari, A, and Thies, E. (2014). The impact of technology transfer through foreign direct investment in developing nations: a case study in the United Arab Emirates. International Journal of Economics and Finance Vol. 6, No. 7; 2014. http://www.ccsenet.org/journal/index.php/ijef/article/view/36200.

Montes M.F. (1997). Direct foreign investment and technology transfer in ASEAN. ASEAN Economic Bulletin Vol. 14. No. 2, pp. 176-189.

Mwega, F. M., \& Ngugi, R. W. (2007). Foreign direct investment in Kenya. In S. I. Ajayi (Ed.), Foreign direct investment in Sub-Saharan Africa: origins, targets, impact and potential.

Ngowi, H. P. (2001). Can Africa increase its global share of foreign direct investment (FDI)? West African Review, 2(2), 1-9.

O'Brien, F. S., \& Ryan, T. C. (2001). Aid and reform in Africa: lessons from ten case studies. Washington D.C.: The World Bank Survey.

OECD, (2010). Innovation Strategy: Getting a Head Start on Tomorrow. Paris: OECD Publishing.

Opolot, J. Mutenyo, J. \& Kalio, A., (2009). Determinants of Foreign Direct Investment: New Evidence from Sub-Saharan Africa. Bank of Uganda Vol. 3 No.2, The Bank of Uganda Staff Papers. Kampala: Bank of Uganda Publication.

Park, J. (2004). International student flows and R\&D spillovers. Economic Letters, 82, 315-20.

Phillips, L. \& Obwana, M. (2000). Foreign direct investment in East Africa: interaction and policy implications. African Economic Policy Discussion Paper number 67. pp. 1-19.

Plunket, A., Voisin, C., \& Bellon, B. (2001). The dynamics of industrial collaboration. Cheltenham: Northampton.

.Porter, M.E., and Stern, S. (2002). "National innovation capacity," In the Competitiveness Report, ed. by Porter, M. E., Sachs, J.D., Cornelius, P.K., McArthur, J.W. and Schwab, K. (Oxford: Oxford University Press, 2001:102).

Rasiah, R., \& Gachino, G. (2005). Are foreign firms more productive, and export and technological intensive than local firms in Kenyan manufacturing? Oxford Development Studies, 33(2), 211-228.

Rutihinda, C. (2007). Impact of globalization on small and medium size firms in Tanzania. Hawaii: ABR and TLC Conference Proceedings.

Romer, P. (1990). Endogenous technological change. The Journal of Political Economy, 98, S71-102.

Sekaran, U., \& Bougie, R. (2013). Research methods for business: a skill-building approach (6th Ed). New York: John Wiley \& Sons. 
Sharma, B., \& Gani, A. (2004). The effects of foreign direct investment on human development. Global Economy Journal, 4(2), 9. Soete, L., \& Patel, P. (1985). Recherche-developpement, importations technologiques et croissance 'economique'. Revue Economique, 36, 975-1000.

Swenson, D. L. (2004). Foreign investment and mediation of trade flows. Review of International Economics, 12(4), 609-29. Todaro, M. (2000). Economic development. Reading: Mass Addison-Wesley.

UNCTAD. (2008). World investment report: transnational corporation and infrastructure challenge. New York and Geneva: United Nations.

UNCTAD. (2001). World investment report 2001: promoting linkages. New York and Geneva: United Nations publication. UNCTAD. (2010). Foreign direct investment, the transfer and diffusion of technology, and sustainable development. New York and Geneva: United Nations publication.

UNCTAD. (2016). World investment report, investor nationality: policy challenges. Geneva: United Nations Publication. UNIDO. (2004). Survey of small and medium enterprises in the global compact. Vienna: UNIDO.

USAID. (2015). Investment brief for the electricity sector in Kenya. Power Africa: USAID. https://www.usaid.gov/powerafrica. van Pottelsberghe, B., \& Lichtenberg, F. (2001). Does foreign direct investment transfer technology across borders? The Review of Economics and Statistics, 83, 490-7.

Wanjala, B. M. (2001). Determinants of foreign direct investment in Sub-Saharan Africa, with inferences on Kenya thesis (M.A.), Nairobi: University of Nairobi.

Wignaraja, G. (2002a). Creating value: from comparative to competitive advantage—competitiveness strategy in developing countries, ITC Executive Forum on National Export Strategies.

World Bank. (2004). Global development finance. Washington: World Bank.

World Bank (2008). Global Development Finance 2008: The Role of International Banking, Volume 2, Summary and Country Tables. Washington, D.C.: World Bank.

Young, S., Hamill, J., Wheeler, C., \& Davies, J. R. (1989). International market entry and development: strategies and management (pp. 10-37).

Young, S. (1998). International business, open learning unit. Glasgow: Strathclyde Graduate Business School.

Zhang, K. (2001). How does FDI affect economic growth in China? Economics of Transition, 9(3), 679-693.

\section{Submit your manuscript to a SpringerOpen ${ }^{\circ}$ journal and benefit from:}

- Convenient online submission

- Rigorous peer review

- Immediate publication on acceptance

- Open access: articles freely available online

- High visibility within the field

- Retaining the copyright to your article

Submit your next manuscript at $>$ springeropen.com 